\title{
AN APPROXIMATE METHOD FOR THE ULTIMATE SHEAR STRENGTH OF HORIZONTALLY CURVED COMPOSITE PLATE GIRDERS
}

\author{
Nandivaram E. SHANMUGAM ${ }^{\mathrm{a}}$, Mohammed A. BASHER ${ }^{\mathrm{b}}$, Khalim A. RASHID ${ }^{\mathrm{a}}$ \\ ${ }^{a}$ Department of Civil and Structural Engineering, Universiti Kebangsaan Malaysia, \\ 43600 UKM Bangi, Selangor, Malaysia \\ ${ }^{b}$ Department of Building and Structural Engineering Technology, \\ Technical College in Mosul, 101 Festival str., Iraq
}

Received 23 Feb 2012; accepted 08 Jun 2012

\begin{abstract}
The paper is concerned with the ultimate load capacity of horizontally curved composite plate girders. An approximate method to predict the ultimate shear strength of the girders is presented. The proposed method accounts for the tension field action in web panels, composite action between steel plate girder and reinforced concrete slab with full interaction and presence of web openings. The accuracy of the method is assessed by comparing the predicted values of ultimate shear strength with the corresponding results obtained by using the nonlinear finite element analyses through a computer package LUSAS. The comparisons show that the proposed method is capable of predicting the ultimate shear strength with an acceptable accuracy. Presence of web openings of different proportions and their effects on ultimate strength of the girders are examined. Girders with trapezoidally corrugated webs are also considered in the study.
\end{abstract}

Keywords: design and construction, composite plate girders, horizontally curved, ultimate shear strength, tension field, approximate method, corrugated webs, web openings.

Reference to this paper should be made as follows: Shanmugam, N. E.; Basher, M. A.; Rashid, K. A. 2014. An approximate method for the ultimate shear strength of horizontally curved composite plate girders, Journal of Civil Engineering and Management 20(3): 330-337. http://dx.doi.org/10.3846/13923730.2013.801913

\section{Introduction}

Horizontally curved plate girders are frequently employed in the construction of modern highway bridges (Hall 1996) in view of their aesthetic appearance and ease of construction where the road alignment requires such curvature. Ultimate strength of these girders under external loads is notably decreased in view of the initial curvature. As the curvature increases excessive deflections may occur. Vertical displacements and rotations are not independent but coupled in the horizontally curved beams. In practice, rotation is often restrained by providing lateral supports such as cross frames, diaphragms and bracings connecting two or more parallel girders. Comprehensive studies on horizontally curved composite plate girders appear to be very limited in the published literature. With the growth in rapid transport systems that rely on close deflection tolerances it is imperative to study the behavior of such curved girders closely, in order to achieve an efficient and effective design approach. An experimental investigation on full-scale horizontally curved steel plate girders has been carried out by Zureick et al. (2002). They studied in detail the overall behavior and ultimate shear strength. Horizontally curved steel plate girders of medium size with and without web openings were tested to failure (Shanmugam et al. 2003; Lian,
Shanmugam 2003) in order to examine the ultimate load behavior and load carrying capacity. Finite element modelling of the girders was also proposed. Jung and White (2006) have reported results obtained from the finite element analyses of full-scale curved girders tested by Zureick et al. (2002). Both the elastic shear bucking and full nonlinear maximum shear strength responses have been considered.

Composite action between plate girders and concrete slab has been studied in the early eighties in respect of straight girders. An experimental investigation on steelconcrete composite plate girders under combined shear and negative bending was carried out by Allison et al. (1982). Based on the experimental results and Cardiff analytical model (Porter et al. 1975; Evans et al. 1978), Allison et al. (1982) proposed equations to determine the collapse load of composite plate girders. In a recent study on horizontally curved composite plate girders Shanmugam et al. (2009) and Basher et al. (2009, 2011) have researched into the behavior and ultimate shear strength by using the finite element modelling and proposed simple methods to determine the shear strength of these girders. The study included the effects of web openings and trapezoidally corrugated webs. This paper is concerned with an approximate method to predict the ultimate shear strength of horizontally curved composite plate girders. 
Effects of openings in the web panels and trapezoidally corrugated webs are also accounted for in the method. The accuracy of the method is established by comparing the results with the corresponding values obtained by using the finite element method.

\section{Ultimate shear strength}

\subsection{Shear strength of straight girders with solid webs}

An equilibrium solution based on tension filed theory was proposed by Porter et al. (1975) and Evans et al. (1978) to calculate the ultimate strength of straight steel plate girders in which it was assumed that shear in a plate girder is resisted by the web plate up to the elastic load (Fig. 1(a)). Any further increase in the load results in formation of buckles parallel to the tensile direction (Fig. 1(b)). Small band of web plate along the tensile diagonal begins to behave in a mode similar to tension member of an $N$-truss. Membrane tension in the web is developed which enables the web to sustain loads well in excess of the elastic critical load. A consequence of this membrane tension is the inward pulling of the flanges, under increasing loads. Eventually plastic hinges are formed in the flanges leading to collapse of the girder (Fig. 1(c)). In view of this type of behavior observed, collapse load of a plate girder is assumed to consist of three components viz. (i) load corresponding to the elastic buckling stage (ii) load resisted by tension field action and (iii) load contributed by the flanges. As per the equilibrium solution (Porter et al. 1975; Evans et al. 1978), the ultimate shear resistance $\left(V_{s}\right)$ of a straight steel plate girder of uniform cross-section with slender webs is given by:

$$
V_{s}=\tau_{c r} d t+\sigma_{t}^{y}(d \cot \theta-b+c) \sin ^{2} \theta+\frac{4 M_{p f}}{c} .
$$

In the above equation, $\tau_{c r}$ refers to the elastic critical shear stress in the web, $\sigma_{t}^{y}$ the membrane stress in the web in post-critical stage, $b$, web panel width, $c$, distance between the hinges formed in the flange, $d$, web depth, $t$, web thickness, $M_{p f}$, plastic moment of the flange and $\theta$, the angle of inclination of the tensile membrane stress $\sigma_{t}^{y}$. It has been proposed (Porter et al. 1975; Evans et al.
1978), based on a number of observations, that $\theta$ can be calculated as:

$$
\theta=\frac{2}{3} \tan ^{-1}\left(\frac{d}{b}\right) .
$$

The value of $c$ is determined from the equation:

$$
c=\frac{2}{\sin \theta} \sqrt{\left(\frac{M_{p f}}{\sigma_{t}^{y} t}\right)} .
$$

Membrane stress, $\sigma_{t}^{y}$ is obtained from:

$\sigma_{t}^{y}=-\frac{3}{2} \tau_{c r} \sin 2 \theta+\sqrt{\left(\sigma_{y w}^{2}+\tau_{c r}^{2}\left\{\left(\frac{3}{2} \sin 2 \theta\right)^{2}-3\right\}\right)}$,

in which $\sigma_{y w}$ is yield stress for the web material.

Shanmugam and Baskar (2006) extended this method to determine the ultimate shear capacity of straight composite plate girders. It was assumed that the ultimate shear capacity of straight composite plate girders $\left(V_{u l t}\right)$ may be obtained as a sum of the shear resistance of bare steel plate girder $\left(V_{s}\right)$, as given in Eqn (1) and the contribution by concrete slab to the shear capacity $\left(V_{c}\right)$, i.e.:

$$
V_{u l t}=V_{s}+V_{c} \text {. }
$$

Test results (Baskar, Shanmugam 2003; Shanmugam, Baskar 2003) have shown that width of the tension field increases due to composite action between steel girder and concrete slab, and the final sway mechanism in the steel part of the composite girders is similar to the mechanism proposed for steel plate girders subjected to shear loading. Three different failure mechanisms in the concrete slab at different stages of loading were observed during the tests. At the initial stages of loading and up to the elastic buckling of web, the composite girders acted like composite beams with hot rolled sections and, the slab was subjected to flexural hairline cracking near the load point and over the two end supports. After the initial hairline cracks in the slab, the girders continued to resist loading without any noticeable change in the stiffness of the girder. The second mode of cracks that were observed

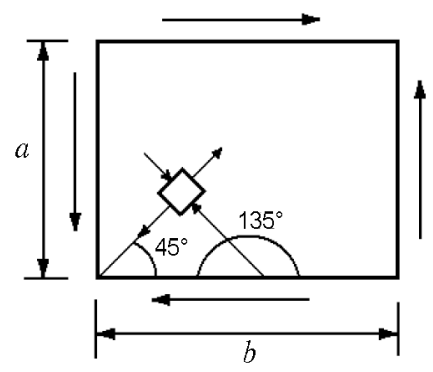

(a) Elastic buckling stage

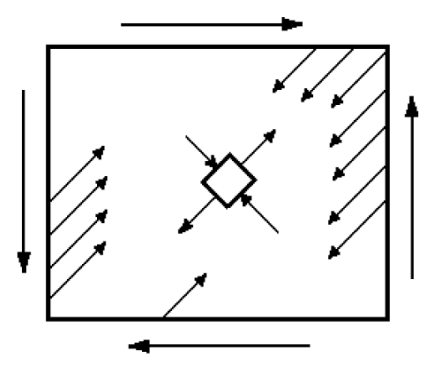

(b) Post-buckling stage

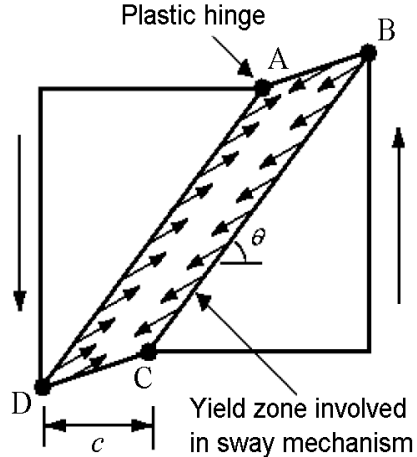

(c) Collapse stage

Fig. 1. Three stages in the collapse behaviour of plate girder webs 
in the girders under shear loading was a cone shaped pullout failure cracks at the end of the girders. These cracks affected the stiffness of the composite girder to a certain extent but allowed the girder to continue to resist further load. At the ultimate condition the concrete slab was subjected to sudden failure in the form of split tensile failure, as shown in Figure 2(a). Based on the experimental observations, a failure mechanism is assumed as shown in Figure 2(b) to calculate the ultimate shear carrying capacity.

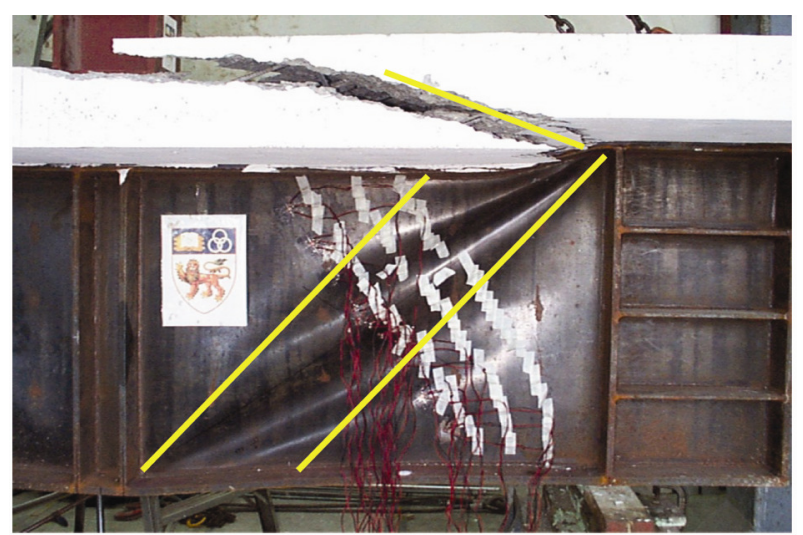

Fig. 2(a). Failure pattern observed by Baskar and Shanmugam (2003)

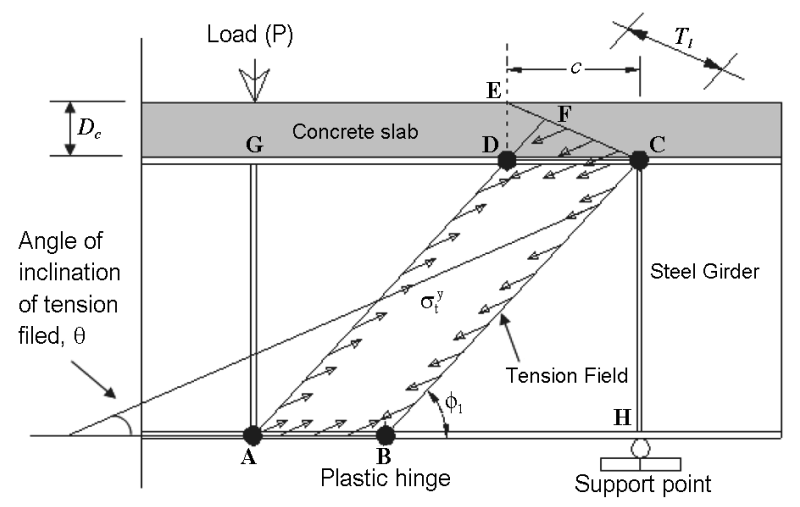

Fig. 2(b). Failure mechanism assumed by Shanmugam and Baskar (2003)

It is assumed herein that the tension field theory for steel plate girders (Porter et al. 1975; Evans et al. 1978) is applicable to determine the shear capacity of steel part $\left(V_{s}\right)$ of the composite plate girders. The diagonal tension field in the web of steel-concrete composite plate girder is partly anchored to the concrete slab through composite action and therefore, shear carrying capacity is enhanced. The extent of tension field anchored by the slab depends on the plastic hinge location, angle of inclination of the tension field, tensile strength of concrete, and the shear strength of concrete slab. Composite action increases the load carrying capacity of the girder due to additional anchorage to the tension field. The contribution by the slab to shear carrying capacity of steel-concrete composite plate girder is given by:

$$
V_{c}=b_{c} \times T_{l} \times f_{t a},
$$

where: $b_{c}$ is effective width of the slab; $T_{l}$ anchor length and $f_{t a}$ allowable split tensile stress of concrete. The value of $b_{c}$ may be taken as the effective width of concrete slab determined based on the code provisions. For an isolated composite girder such as those considered in the present study the whole width of the slab may be assumed effective especially under shear loading. $T_{l}$ is determined from the assumed failure mechanism shown in Figure 2. It is assumed that the anchor plane lies along the line $C E$ and inclined at an angle of $\phi_{2}$ with respect to the connecting steel flange (assumed horizontal). The magnified view of the portion $C D E F$ is shown in Figure 3. The node $E$ in the concrete slab lies on a vertical line through node $D$. The anchor plane is assumed to lie in the plane connecting the nodes $C$ and $E$. Even though the anchor plane is between the nodes $C$ and $E$, the effective anchor length, $T_{l}$, is taken as the length between the nodes $C$ and $F$ and determined from the geometry in Figure 3.

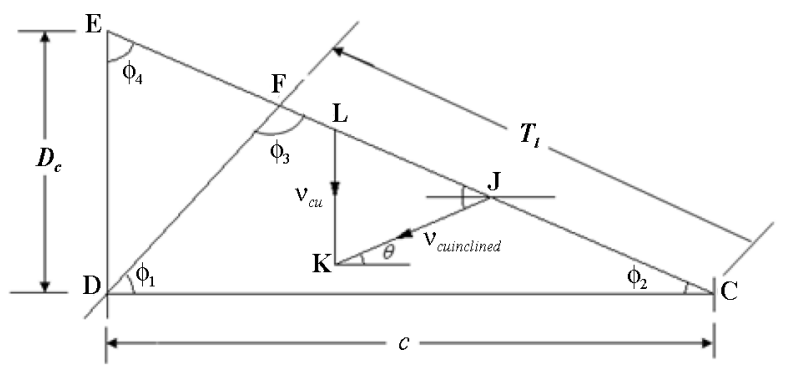

Fig. 3. Magnified view of the portion $C D E F$ shown in Figure 2

The allowable split tensile stress, $f_{t a}$, along the anchor plane is a parameter dependant on the angle of inclination of the anchor plane, angle of inclination of tension field and the maximum allowable shear and tensile strength of concrete. At the ultimate load condition, it is assumed that the shear strength of concrete will reach to its maximum value. The allowable split tensile stress, $f_{t a}$, along the anchor plane is taken as $f_{t a}=f_{\text {tu }}-v_{\text {cuinlined }}$ in which $f_{t u}$ is the measured ultimate split tensile stress of concrete. Codes and researchers have recommended different values of $v_{c u}$ for an un-reinforced and minimum reinforced concrete sections. Narayanan et al. (1989), related this value $v_{c u}$ approximately to the concrete cube strength, $f_{c u}$, as $v_{c u}=0.3\left(f_{c u}\right)^{0.5}$. This value of $v_{c u}$ is considered in the present study to determine the contribution of concrete slab on shear carrying capacity of composite plate girders.

\section{Horizontally curved composite plate girders with solid webs}

The method described above was applied to the horizontally curved composite girders with a modification factor $\left(K_{c}\right)$ to account for curvature of the girder. The modification factor, $K_{c}$ for shear force was obtained by considering the bending of horizontally curved beam (Pytel, Singer 1987) shown in Figure 4 as:

$$
K_{c}=\frac{3}{2 \alpha}\left(\sin \alpha-\sin \frac{\alpha}{3}\right),
$$


where $\alpha$ is the included angle at the centre of curvature. The curvature factor $K_{c}$ can be used to obtain shear force at specified points along the curved girder based on the values corresponding to straight girders. It should be noted that the above equation for $K_{c}$ is independent of number of transverse stiffeners and, the included angle ' $\alpha$ ' is for a single curved span only. The ultimate shear strength of a horizontally curved composite plate girder can thus be calculated as:

$$
V_{\text {ult(curved })}=K_{c}\left(V_{s}+V_{c}\right) .
$$

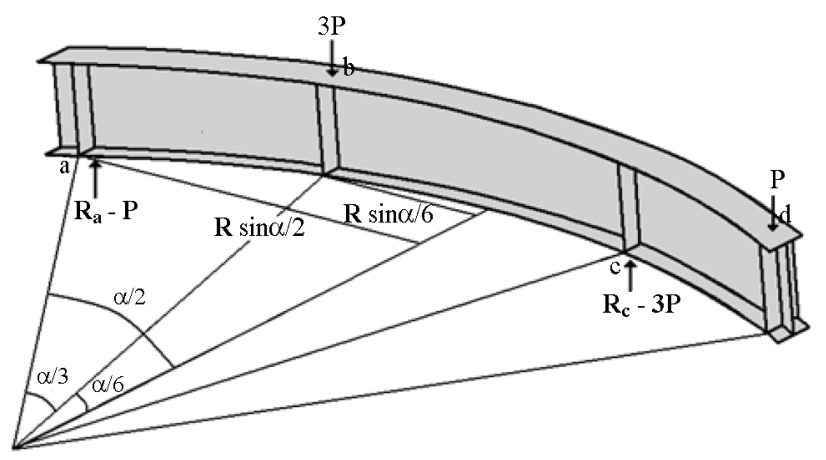

Fig. 4. Bending of a horizontally curved beam

It is necessary to assess the accuracy of any new method proposed. Therefore, horizontally curved composite plate girders with solid webs $C 1, C 2, C 1-C$ and $C 2-C$ reported earlier by the authors (Shanmugam et al. 2009) were considered in this study. The straight girder values of $V_{s}, V_{c}$ and $V_{u l t}$ for the eight girders were determined first and the ultimate strength for the horizontally curved girders was obtained as $V_{\text {ult(curved })}$ equal to the product of $V_{u l t}$ and $K_{c}$. Shear strength values for the girders obtained from finite element analyses using LUSAS, $V_{\text {ultFEA }}$ are listed along with $V_{\text {ult(curved) }}$ in Table 1 for comparison. It can be seen from the table that there is a close agreement between the finite element and predicted values, the maximum deviation being $4 \%$ thus confirming the accuracy of the proposed method. Despite the approximations, the proposed method is found to be capable of predicting the shear capacity of the horizontally curved composite plate girders to an acceptable accuracy.

\section{Horizontally curved composite plate girders with web openings}

For plate girder with web openings additional load in the post critical stage is carried by the membrane stresses, $\sigma_{t}^{y}$ which form two tension bands in the web, one above and the other below the openings, as shown in Figure 5 (Narayanan, Rockey 1981). The distance $c$ between hinges and the angle of inclination of the panel diagonal $\theta_{d}$ are shown in the figure. A suitable value for the angle of inclination of the tensile membrane stress $\theta_{d}$ is chosen appropriate to the perforated web. Narayanan and Avanessian $(1983 \mathrm{a}, \mathrm{b})$ have suggested that for a perforated web the angle may be taken as:

$$
\theta_{d}=\frac{2}{3} \theta\left(1-\frac{d_{o}}{d}\right) \text { or } \theta_{d}=\frac{2}{3} \theta\left(1-\frac{b_{o}}{b}\right),
$$

whichever is smaller.

$d_{o}$ and $b_{o}$ are, respectively the depth and width of the rectangular openings, $d$ and $b$ being, respectively depth and width of the web panel.

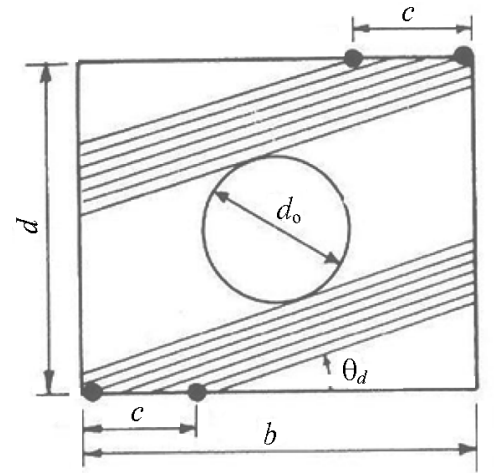

Fig. 5. Tension bands formed for circular holes

The ultimate strength, $V_{s}$ of a straight plate girder containing centrally located circular or square opening can be obtained as:

$$
\begin{aligned}
V_{s}= & \left(\tau_{c r}\right)_{r e d} d t+2 c t \sigma_{t}^{y} \sin ^{2} \theta_{d}+ \\
& \sigma_{t}^{y} t d\left(\cot \theta_{d}-\cot \theta\right) \sin ^{2} \theta_{d}-\sigma_{t}^{y} t d_{o} \sin \theta_{d},
\end{aligned}
$$

where $\left(\tau_{c r}\right)_{\text {red }}$ is the reduced value of elastic critical shear stress of the web containing a hole given as:

$$
\left(\tau_{c r}\right)_{\text {red }}=k \frac{\pi^{2} E}{12\left(1-v^{2}\right)}\left(\frac{t}{d}\right)^{2} \text {. }
$$

Table 1. Comparison of results for girders with solid webs

\begin{tabular}{c|c|c|c|c|c|c|c}
\hline \multirow{2}{*}{ Girders } & $\begin{array}{c}b_{f} \\
m m\end{array}$ & $\begin{array}{c}V_{c} \\
k N\end{array}$ & $\begin{array}{c}V_{s} \\
k N\end{array}$ & $\begin{array}{c}V_{\text {ultpred }} \\
k N\end{array}$ & $\begin{array}{c}V_{\text {ult(curved })} \\
k N\end{array}$ & $\begin{array}{c}V_{\text {ultFEA }} \\
k N\end{array}$ & $\frac{V_{\text {ult(curved })}}{V_{\text {ultFEA }}}$ \\
\hline \multirow{2}{*}{$C 1$} & 203.3 & 565 & 1588 & 2153 & 1433 & 1419 & 1.01 \\
& 546.6 & 834 & 1801 & 2635 & 1754 & 1703 & 1.03 \\
\hline \multirow{2}{*}{$C 1-C$} & 203.3 & 798 & 1696 & 2494 & 1660 & 1643 & 1.01 \\
& 546.4 & 1007 & 1946 & 2953 & 1966 & 1927 & 1.02 \\
\hline \multirow{2}{*}{$C 2$} & 203.3 & 482 & 1503 & 1985 & 1317 & 1304 & 1.01 \\
& 557.3 & 681 & 1742 & 2423 & 1608 & 1546 & 1.04 \\
\hline \multirow{2}{*}{$C 2-C$} & 203.3 & 879 & 1677 & 2556 & 1696 & 1713 & 0.99 \\
& 556.3 & 952 & 1837 & 2789 & 1851 & 1833 & 1.01 \\
\hline
\end{tabular}


Table 2. Comparison of results for girders with perforated webs

\begin{tabular}{|c|c|c|c|c|c|c|c|c|c|}
\hline Girder & $\theta$ & $\begin{array}{c}c \\
m m\end{array}$ & $\begin{array}{c}T_{l} \\
m m\end{array}$ & $\begin{array}{l}V_{c} \\
k N\end{array}$ & $\begin{array}{c}V_{s} \\
k N\end{array}$ & $\begin{array}{l}V_{u l t} \\
k N\end{array}$ & $\begin{array}{c}V_{\text {ult(curved) }} \\
k N\end{array}$ & $\begin{array}{c}V_{\text {ultFEA }} \\
k N\end{array}$ & $\frac{V_{\text {ult(curved })}}{V_{\text {ultFEA }}}$ \\
\hline$C 1-\operatorname{Cr} 0.1 D$ & 17 & 713 & 73 & 653 & 1900 & 2553 & 1699 & 1668 & 1.02 \\
\hline$C 1-\operatorname{Cr} 0.2 D$ & 15 & 769 & 71 & 587 & 1686 & 2273 & 1513 & 1480 & 1.02 \\
\hline$C 1-\mathrm{Cr} 0.3 D$ & 14 & 795 & 69 & 525 & 1527 & 2052 & 1366 & 1320 & 1.03 \\
\hline$C 1-\mathrm{Cr} 0.4 D$ & 12 & 894 & 67 & 438 & 1225 & 1663 & 1107 & 1130 & 0.98 \\
\hline$C 1-\operatorname{Cr} 0.5 D$ & 10 & 1041 & 65 & 419 & 1112 & 1531 & 1019 & 1040 & 0.98 \\
\hline$C 1-\mathrm{Sq} 0.1 D$ & 15 & 794 & 71 & 604 & 1950 & 2554 & 1700 & 1644 & 1.03 \\
\hline$C 1-\mathrm{Sq} 0.2 D$ & 13 & 873 & 70 & 578 & 1662 & 2249 & 1497 & 1457 & 1.03 \\
\hline$C 1-\mathrm{Sq} 0.3 D$ & 11 & 991 & 67 & 498 & 1587 & 2085 & 1388 & 1302 & 1.06 \\
\hline$C 1-\mathrm{Sq} 0.4 D$ & 10 & 1171 & 65 & 438 & 1117 & 1555 & 1035 & 1093 & 0.95 \\
\hline$C 1-\mathrm{Sq} 0.5 D$ & 9 & 1289 & 64 & 404 & 1040 & 1444 & 953 & 1005 & 0.95 \\
\hline
\end{tabular}

Narayanan and Der Avanessian (1983a, b) have demonstrated that in calculating $\left(\tau_{c r}\right)_{\text {red }}$, the value of $k$ appropriate to a web fixed at its edges should be used. This is justified as, when there is a hole, the stiffness of the flange is much higher than that of the web and the behaviour of the web plate is closer to the one having encastre' supports. The value of $k$ is obtained as:

$$
k=k_{o}\left(1-\frac{d_{o}}{d}\right)
$$

where:

$$
k_{o}=8.98+5.6\left(\frac{d}{b}\right)^{2} \text { for } \frac{b}{d}>1.0
$$

Membrane stress can be evaluated as:

$$
\begin{aligned}
\sigma_{t}^{y}= & -\frac{3}{2}\left(\tau_{c r}\right)_{\text {red }} \sin 2 \theta_{d}+ \\
& \sqrt{\left\{\sigma_{y w}^{2}+\left(\tau_{c r}\right)^{2}\left[\left(\frac{3}{2} \sin 2 \theta_{d}\right)^{2}-3\right]\right\}} .
\end{aligned}
$$

The contribution by concrete slab to shear capacity of the girder is determined based on the assumed failure mechanism shown in Figure 6. Since there is no observed buckled pattern of webs for composite plate girders with web openings, the buckled pattern corresponding to girder with solid webs is assumed approximately for this case.

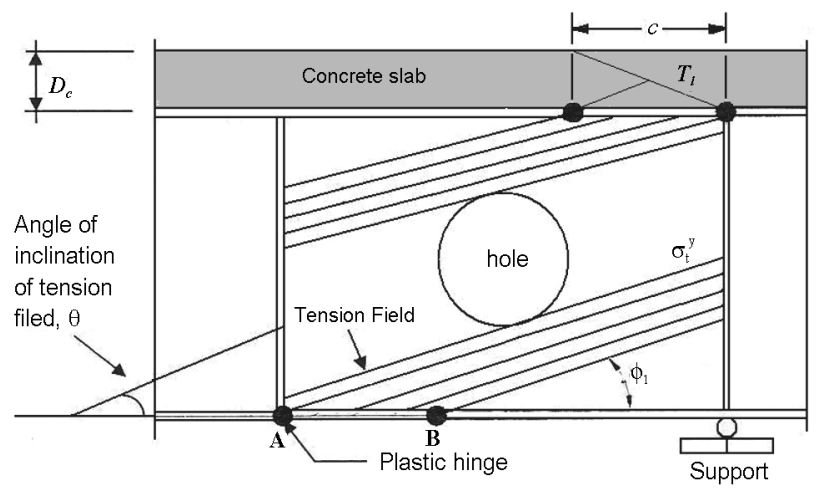

Fig. 6. Failure mechanism of girders with openings in the web
Ultimate shear strength, $V_{s}$ of the straight steel girder with web openings, is obtained by Eqn (10) and the corresponding values for composite girder, straight or curved, are determined using Eqns (5) and (8), respectively. The accuracy of the method is assessed by considering the girder $C 1$ referred in the previous section. Circular or square openings, of size ranging from $0.1 D$ to $0.5 D$, $D$ being the girder depth, were introduced in each of the web panels and the girders with web openings analyzed using the proposed method. The straight girder values of $V_{s}, V_{c}$ and $V_{u l t}$ and the curved girder values for the ten girders, $V_{\text {ult (curved) }}$ are summarized in Table 2 . The corresponding shear strength values, $V_{\text {ultFEA }}$ for the girders obtained from the finite element analyses using LUSAS, are also listed in Table 2 for comparison. It can be seen from the table that there is a close agreement between the finite element and predicted values, the maximum deviation being $6 \%$ thus confirming the accuracy of the proposed method.

\section{Horizontally curved composite plate girders with trapezoidally corrugated webs}

Corrugated profile in webs similar to those shown in Figure 7 provides a kind of uniformly distributed stiffening in the transverse direction of a girder and also increases the out-of-plane stiffness and buckling strength. Compared to plate girders with stiffened flat webs a girder with a corrugated web enables the use of thinner webs, thus a higher load-carrying capacity is achieved for a lower cost. Girders with trapezoidally corrugated webs are considered in this paper.

Eqn (1) is modified to account for corrugated webs assuming tension zone developing across the diagonal of a web panel. Global (overall) buckling of a corrugated web panel is characterized by diagonal buckling over several corrugation panels. The critical shear stress for this mode is estimated by considering the corrugated web as an orthotropic plate. The critical shear stress of this mode, $\tau_{\text {crg }}$ is obtained as (Galambos 1998):

$$
\tau_{c r g}=k_{g} \frac{\left(D_{y} D_{x}^{3}\right)^{0.25}}{d^{2} t_{w}},
$$

where: $k_{g}$ is the global shear buckling coefficient which depends solely on the web top and bottom constraints. $k_{g}$ 
is 36 for steel girders (Luo, Edlund 1994; Sayed-Ahmed 2001, 2005). The factors $D_{x}$ and $D_{y}$ are the flexural stiffness per unit corrugation about the longitudinal and transverse axes, respectively (Fig. 7). $D_{x}$ and $D_{y}$ are given as (Elgaaly et al. 1996; Johnson, Cafolla 1997):

$$
\begin{gathered}
D_{x}=\frac{E}{b_{h}+d_{t z}}\left(\frac{b_{h} t_{w} h^{2}}{4}+\frac{t_{w} h^{3}}{12 \sin \beta}\right) ; \\
D_{y}=\left(\frac{b_{h}+d_{t z}}{b_{h}+a}\right)\left(\frac{E t_{w}^{3}}{12}\right) .
\end{gathered}
$$
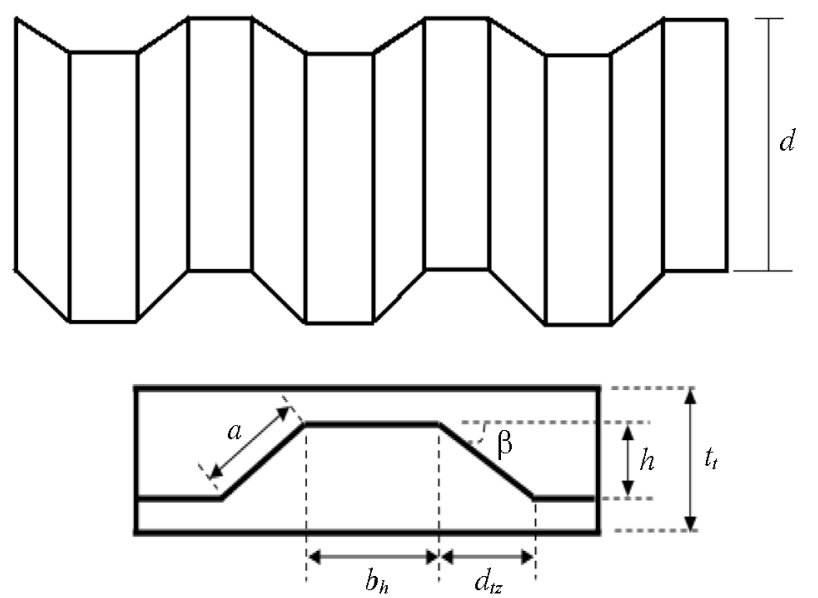

Fig. 7. Trapezoidal profile of the corrugated web plates

It is assumed in this case that buckling occurs diagonally over a number of corrugations within a web panel as shown in Figure 8 and, therefore, global buckling governs the collapse of the girder. The failure of the girder occurs when the buckled portion of the corrugated web panel yields and a mechanism is developed with hinges formed in the flanges. The ultimate shear strength of the steel part of the girder is assumed to be given by:

$$
V_{s}=\tau_{c r g} d t_{w}+\sigma_{t}^{y} t_{w} \sin ^{2} \theta(d \cot \theta-b)+2 c t_{w} \sigma_{t}^{y} \sin ^{2} \theta \text {. }
$$

The value of $\theta$ and $c$ can be evaluated by Eqns (2) and (3), respectively. $\sigma_{t}^{y}$ is given as:

$$
\sigma_{t}^{y}=-\frac{3}{2} \tau_{c r g} \sin 2 \theta+\sqrt{\left\{\sigma_{y w}^{2}+\tau_{c r g}^{2}\left[\left(\frac{3}{2} \sin 2 \theta\right)^{2}-3\right]\right\}} .
$$

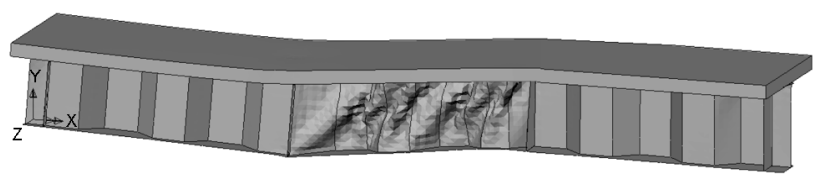

Fig. 8. Global buckling in a panel of a plate girder with corrugated webs

The contribution by concrete slab to shear capacity of the girder is determined based on the assumed failure mechanism shown in Figures 2 and 3 and, it is given by Eqn (6). The ultimate strength obtained as above for a straight girder is multiplied by a constant $K_{c}$ given in Eqn (7) to account for the curvature in a curved girder.

Girders with different values of corrugation width, corrugation height and corrugation inclinations as shown in Table 3 were analyzed for ultimate strength using the proposed method in order to verify the accuracy of the method. For all the fifteen composite girders, $C T 1-C T 15$, the contributions by steel part of the straight girders, $V_{s}$ were determined first and then the increase in shear resistance due to concrete slab, $V_{c}$ obtained. The combined values $V_{u l t}$ give the ultimate shear strength for straight girders which when multiplied by the curvature factor $K_{c}$ yields the corresponding values for curved girders, $V_{u l(\text { curved) }}$. These values of ultimate strength and the corresponding values determined by finite element analyses are summarized along with the comparison between the two values in Table 3. It can be seen from the table that there is a close agreement between the finite element and predicted values, the maximum deviation being $8 \%$ thus confirming the accuracy of the proposed method. Despite the approximations the proposed method is found to be capable of predicting the shear capacity of the horizontally curved composite plate girders with corrugated webs to an acceptable accuracy.

Table 3. Comparison of shear strength for girders with solid webs

\begin{tabular}{l|l|c|c|c|c|c|c|c|c|c}
\hline Girder & $\beta$ & $\begin{array}{c}h \\
m m\end{array}$ & $\begin{array}{c}b_{h} \\
m m\end{array}$ & $\begin{array}{c}a \\
m m\end{array}$ & $\begin{array}{c}V_{c} \\
k N\end{array}$ & $\begin{array}{c}V_{s} \\
k N\end{array}$ & $\begin{array}{c}V_{\text {ult }} \\
k N\end{array}$ & $\begin{array}{c}V_{\text {ult(curved) }} \\
k N\end{array}$ & $\begin{array}{c}V_{\text {ultFEA }} \\
k N\end{array}$ & $\begin{array}{c}V_{\text {ult(curved })} \\
V_{\text {ultFEA }}\end{array}$ \\
\hline CT1 & 37 & 300 & 20 & 501 & 823 & 2578 & 3401 & 2245 & 2388 & 0.94 \\
CT2 & 37 & 300 & 100 & 501 & 858 & 2850 & 3708 & 2447 & 2523 & 0.97 \\
CT3 & 37 & 300 & 300 & 501 & 814 & 2504 & 3318 & 2190 & 2274 & 0.96 \\
CT4 & 37 & 300 & 500 & 501 & 796 & 1999 & 2795 & 1845 & 1922 & 0.96 \\
CT5 & 37 & 300 & 750 & 501 & 774 & 1855 & 2629 & 1735 & 1827 & 0.95 \\
CT6 & 45 & 100 & 500 & 141 & 721 & 1864 & 2585 & 1706 & 1796 & 0.95 \\
CT7 & 45 & 200 & 500 & 283 & 756 & 1983 & 2739 & 1808 & 1903 & 0.95 \\
CT8 & 45 & 300 & 500 & 424 & 822 & 2148 & 2970 & 1960 & 2042 & 0.96 \\
CT9 & 45 & 400 & 500 & 566 & 862 & 2256 & 3118 & 2058 & 2144 & 0.96 \\
CT10 & 45 & 500 & 500 & 707 & 924 & 2253 & 3177 & 2097 & 2231 & 0.94 \\
CT11 & 90 & 100 & 500 & 100 & 718 & 2282 & 3000 & 1980 & 1833 & 1.08 \\
CT12 & 90 & 200 & 500 & 200 & 792 & 2487 & 3279 & 2164 & 2004 & 1.08 \\
CT13 & 90 & 300 & 500 & 300 & 846 & 2568 & 3414 & 2253 & 2187 & 1.03 \\
CT14 & 90 & 400 & 500 & 400 & 904 & 2769 & 3673 & 2424 & 2309 & 1.05 \\
CT15 & 90 & 500 & 500 & 500 & 948 & 3014 & 3962 & 2615 & 2467 & 1.06 \\
\hline
\end{tabular}




\section{Conclusions}

An approximate method to predict the ultimate shear strength of horizontally curved composite plate girders has been presented. Girders with solid webs, perforated webs and trapezoidally corrugated webs have been considered in the study. The proposed method is based on the Cardiff model for the collapse behaviour of straight plate girders which is governed by tension field action in the web panels. Effects of parameters such as curvature in plan, composite action between the steel part of the girder and the reinforced concrete slabs, openings in the web and corrugated webs have been examined in the study. A number of girders covering the parameters mentioned above have been analyzed using the proposed method and the ultimate shear strength has been predicted. These results are compared with the corresponding values determined by the nonlinear finite element analyses in order to assess the accuracy of the proposed method. It has been observed from the comparison that the proposed method is capable of predicting the ultimate shear strength with an acceptable accuracy and hence the method could be used for design office applications. It should, however, be noted that the proposed method and the accompanying verifications are purely based on theoretical studies and, the accuracy of web capacity predicted needs confirmation through experimental studies. The authors hope to report such experimental studies in due course.

\section{References}

Allison, R. W.; Johnson, R. P.; May, I. M. 1982. Tension field action in composite plate girders, in Proc. of the Instn. of Civil Engrs 73(2): 255-276.

http://dx.doi.org/10.1680/iicep.1982.1700

Basher, M. A.; Shanmugam, N. E.; Khalim, A. R. 2009. Web openings in horizontally curved composite plate girders, Journal of Constructional Steel Research 65(8): 16941704. http://dx.doi.org/10.1016/j.jcsr.2009.02.009

Basher, M. A.; Shanmugam, N. E.; Khalim, A. R. 2011. Horizontally curved composite plate girders with trapezoidally corrugated webs, Journal of Constructional Steel Research 67(6): 947-956.

http://dx.doi.org/10.1016/j.jcsr.2011.01.015

Baskar, K.; Shanmugam, N. E. 2003. Steel-concrete composite plate girders subject to combined shear and bending, Journal of Constructional Steel Research 59(4): 531-557. http://dx.doi.org/10.1016/S0143-974X(02)00042-1

Elgaaly, M.; Hamilton, R. W.; Seshadri, A. 1996. Shear strength of beams with corrugated webs, Journal of Structural Engineering, ASCE 122(4): 390-398. http://dx.doi.org/ 10.1061/(ASCE)0733-9445(1996)122:4(390)

Evans, H. R.; Porter, D. M.; Rockey, K. C. 1978. The collapse behavior of plate girders subjected to shear and bending, International Association for Bridge and Structural Engineering, 18-78.

Galambos, T. V. 1998. Guide to stability design criteria for metal structures. $5^{\text {th }}$ ed. New York: John Wiley and Sons.

Hall, D. H. 1996. Curved girders are special, Engineering Structures 18(10): 769-777.

http://dx.doi.org/10.1016/0141-0296(96)00012-0
Johnson, R. P.; Cafolla, J. 1997. Corrugated webs in plate girders for bridges, Structures and Buildings, ICE 123: 157164. http://dx.doi.org/10.1680/istbu.1997.29305

Jung, S. K.; White, D. W. 2006. Shear strength of horizontally curved steel I girders - finite element analysis studies, Journal of Constructional Steel Research 62(4): 329-342. http://dx.doi.org/10.1016/j.jcsr.2005.08.003

Lian, V. T.; Shanmugam, N. E. 2003. Openings in horizontally curved plate girders, Thin-Walled Structures 41: 245-269. http://dx.doi.org/10.1016/S0263-8231(02)00090-3

Luo, R.; Edlund, B. 1994. Buckling analysis of trapezoidally corrugated panels using spline finite strip method, Thinwalled Structures 18: 209-224. http://dx.doi.org/10.1016/0263-8231(94)90019-1

Narayanan, R.; Al-Amery, R. I. M.; Roberts, T. M. 1989. Shear strength of composite plate girders withrectangular web cutouts, Journal of Constructional Steel Research 12(2): $151-166$. http://dx.doi.org/10.1016/0143-974X(89)90030-8

Narayanan, R.; Der Avanessian, N. G. V. 1983a. Equilibrium solution for predicting the strength of webs with rectangular holes, Proc. Inst. Civ. Eng. 75(2): 265-282. http://dx.doi.org/10.1680/iicep.1983.1503

Narayanan, R.; Der Avanessian, N. G. V. 1983b. Strength of web containing circular cutouts, IABSE Periodica 3: 6483.

Narayanan, R.; Rockey, K. C. 1981. Ultimate load capacity of plate girders with webs containing circular cut-outs, Proc. Inst. Civ. Eng. 71(2): 845-862.

http://dx.doi.org/10.1680/iicep.1981.1822

Pytel, A.; Singer, F. L. 1987. Strength of Materials. $4^{\text {th }}$ ed. New York: Harper Collins College Div.

Porter, D. M.; Rockey, K. C.; Evans, H. R. 1975. The collapse behavior of plate girders loaded in shear, The Structural Engineer 53(8): 313-325.

Sayed-Ahmed, E. Y. 2001. Behaviour of steel and/or composite girders with corrugated steel webs, Canadian Journal of Civil Engineering 28(4): 656-672. http://dx.doi.org/10.1139/101-027

Sayed-Ahmed, E. Y. 2005. Plate girders with corrugated steel webs, AISC Engineering Journal 42(1): 1-13.

Shanmugam, N. E.; Basher, M. A.; Khalim, A. R. 2009. Ultimate load behaviour of horizontally curved composite plate girders, International Journal of Steel and Composite Structures 4: 325-348.

http://dx.doi.org/10.12989/scs.2009.9.4.325

Shanmugam, N. E.; Baskar, K. 2003. Steel-concrete composite plate girders subject to shear loading, Journal of Structural Engineering, ASCE 129(9): 1230-1242. http://dx.doi.org/10.1061/(ASCE)0733-9445(2003)129: 9(1230)

Shanmugam, N. E.; Baskar, K. 2006. Design of composite plate girders under shear loading, International Journal of Steel and Composite Structures 6(1): 1-14. http://dx.doi.org/10.12989/scs.2006.6.1.001

Shanmugam, N. E.; Mahendrakumar, M.; Thevendran, V. 2003. Ultimate load behaviour of horizontally curved plate girders, Journal of Constructional Steel Research 49(4): 509-529. http://dx.doi.org/10.1016/S0143-974X(02)00043-3

Zureick, A. H.; White, D. W.; Phoawanich, N.; Park, J. 2002. Shear strength of horizontally curved steel I girders experimental tests, in Final report to Professional Services Industries, Inc. and Federal Highway Administration. 
Nandivaram E. SHANMUGAM. Professor at the Department of Civil and Structural Engineering, Universiti Kebangsaan Malaysia (UKM). He obtained his PhD degree from the University of Wales (Cardiff) in 1978. He has taught at undergraduate and graduate levels for more than 45 years. He has published more than 200 scientific papers in international journals and conference proceedings. He is a member of the editorial board of Journal of Constructional Steel Research, Thin-Walled Structures, Journal of Structural Stability and Dynamics, International Journal of Steel Composite Structures, International Journal of Steel Structures and IES Journal Part A: Civil and Structural Engineering. He is a Chartered Engineer (CEng), Fellow of the Institution of Structural Engineers, London, (FIStructE), Fellow of the Royal Institution of Naval Architects (FRINA), Fellow of the American Society of Civil Engineers (FASCE), Fellow of the Institution of Engineers, Singapore (FIES) and Fellow of the Institution of Engineers, India (FIEI). Research interests include steel plated structures, steel-concrete composite construction, long-span structures and connections, cold-formed steel structures, elastic and ultimate load behaviour of steel structures, etc.

Mohammed A. BASHER. Senior Lecturer at the Department of Building and Structural Engineering Technology, Technical College-Mosul, Iraq. He obtained his PhD degree from the National University of Malaysia (UKM) in 2010. He has taught at undergraduate and graduate levels for more than a year. He has published 11 scientific papers in international journals and conference proceedings. He is a Chartered Engineer (CEng), Fellow of the National Institution of Technical Education, and Fellow of the Institution of Engineers, Iraq. Research interests include steel plated structures, steelconcrete composite construction.

Khalim A. RASHID. Associate Professor at the Department of Civil and Structural Engineering, Universiti Kebangsaan Malaysia (UKM). He obtained his PhD degree from the University of Birmingham in 2000. He taught at undergraduate and graduate levels for more than 20 years. He has published more than 40 scientific papers in national and international journals and conference proceedings. He is a corporate member of the Board of Engineers Malaysia (BEM) and Institution of Engineers Malaysia (IEM). His research interests include reinforced concrete structures, structural steelwork, bridge engineering, and industrialized building systems. 